\title{
Artur Sajnóg*
}

\section{REAKCJE EFEKTYWNOŚCI ORAZ WARTOŚCI RYNKOWEJ NA WZROST KAPITAŁU ZAKŁADOWEGO SPÓŁEK BUDOWLANYCH}

\section{WPROWADZENIE}

W strategicznym zarządzaniu finansami przedsiębiorstw szczególnie ważne miejsce zajmuje kształtowanie wartości i struktury kapitału własnego, od którego zależy m. in. zdolność przedsiębiorstwa do kreowania przyszłych warunków i efektów działań inwestycyjnych, jego wiarygodność czy kapitał relacyjny. Zmiany wielkości i struktury kapitału własnego wywołane są wieloma różnorodnymi strategiami kreacji wyniku finansowego przedsiębiorstwa oraz jego podziałem i zaangażowaniem $\mathrm{w}$ inwestycje. Są to zmiany zorientowane na wzrost lub na zmniejszenie udziału kapitału zakładowego w kapitale własnym przedsiębiorstwa, których źródłem są zarówno osiągnięte roczne wyniki finansowe, jak i strategie pozyskiwania dodatkowego kapitału własnego, przykładowo drogą emisji nowych emisji akcji bądź kapitalizacji rezerw.

Zasadniczym celem opracowania jest udzielenie odpowiedzi na podstawowe następujące pytanie badawcze: czy i w jakim stopniu podwyższenie kapitału zakładowego powiązane jest ze wzrostem efektywności ekonomicznej przedsiębiorstw budowlanych i wzrostem wartości rynkowej budowlanych publicznych spółek akcyjnych?

Dla realizacji celu pracy przyjęto siedem następujących mierników oceny:

- rentowność aktywów całkowitych,

- rentowność kapitału własnego,

- współczynnik kapitalizacji rynkowej,

- współczynnik cena/wartość księgowa oraz

* Dr, Uniwersytet Łódzki, Wydział Ekonomiczno-Socjologiczny, Katedra Analizy i Strategii Przedsiębiorstwa. 
- wskaźnik dynamiki kapitału zakładowego,

- wskaźnik udziału kapitału zakładowego w kapitale własnym oraz

- współczynnik sfinansowania majątku całkowitego kapitałem zakładowym.

Uzasadnienie wyboru i zastosowania powyższych mierników dla znalezienia odpowiedzi na postawione pytanie badawcze zawiera się w dążeniu do bliższego rozpoznania charakteru relacji zachodzących między zmianami kluczowych czynników kształtujących sytuację finansowo-majątkową przedsiębiorstw budowlanych notowanych na GPW w Warszawie w latach w latach 2003-2012.

\section{ROLA KAPITALU PODSTAWOWEGO W ZARZĄDZANIU FINANSAMI PRZEDSIĘBIORSTWA}

Zarządzanie finansami przedsiębiorstwa polega na doborze optymalnej wielkości i struktury funduszy i lokowaniu ich w przedsięwzięciach optymalnych z punktu widzenia realizacji celu przedsiębiorstwa ${ }^{1}$. Jest to proces decyzyjny, w którym określa się różnego rodzaju instrumenty, techniki i sposoby gospodarowania kapitałami w ścisłym związku z realizowanymi procesami produkcji i logistyki oraz marketingu i inwestycji. Proces ten znajduje skonkretyzowany wyraz w pozyskiwaniu źródeł finansowania oraz lokowaniu kapitałów w składniki majątkowe dla maksymalizacji wartości rynkowej przedsiębiorstwa (zob. rys. 1).

Przyjmując do rozważań szersze pojęcie finansowania przedsiębiorstwa, w którym obejmuje ono podejmowanie i realizację wszelkich przedsięwzięć prowadzących do otrzymania kapitału², wskazać można, iż strategia finansowania $^{3}$ określa docelową strukturę kapitału oraz rodzaje instrumentów, które będą wykorzystywane do pozyskiwania kapitału ${ }^{4}$ Nadto, szeroko pojętą strategię finansowania określić można jako szereg decyzji podejmowanych nie tylko w celu pozyskiwania kapitału, ale również dla jego właściwej alokacji w przedsiębiorstwie oraz określenia optymalnej struktury kapitału, zapewniającej maksymalizację efektywności ekonomicznej oraz wartości jednostki.

${ }^{1}$ Z. Fed or o w i c z, Uwagi o przedmiotowym zakresie teorii finansów przedsiębiorstw, [w:] J. Ickiewicz (red.), Problemy finansów w teorii i praktyce, Wydawnictwo SGH, Warszawa 2004, s. 73.

2 J. I c ki e wi c z, Strategia finansowania przedsiębiorstwa, Poltext, Warszawa 1996, s. 8.

${ }^{3} \mathrm{~W}$ literaturze przedmiotu strategia finansowania odnosi się w głównej mierze do źródeł finansowania majątku trwałego i obrotowego bądź wyłącznie do finansowania środków obrotowych. Z tego względu wyróżnia się strategie: zachowawczą, umiarkowaną i dynamiczną oraz przeciętną, agresywną i konserwatywną. Por. M. Si er pińsk a, D. W ę d zki, Zarządzanie ptynnościq finansowa $w$ przedsiębiorstwie, Wydawnictwo Naukowe PWN, Warszawa 2008, s. 103; Z. Fe d or o w i c z, Finanse przedsiębiorstwa, Poltext, Warszawa 1993, s. 155.

${ }^{4}$ A. Dulin ie c, Finansowanie przedsiębiorstwa, PWE, Warszawa 2007, s. 130. 


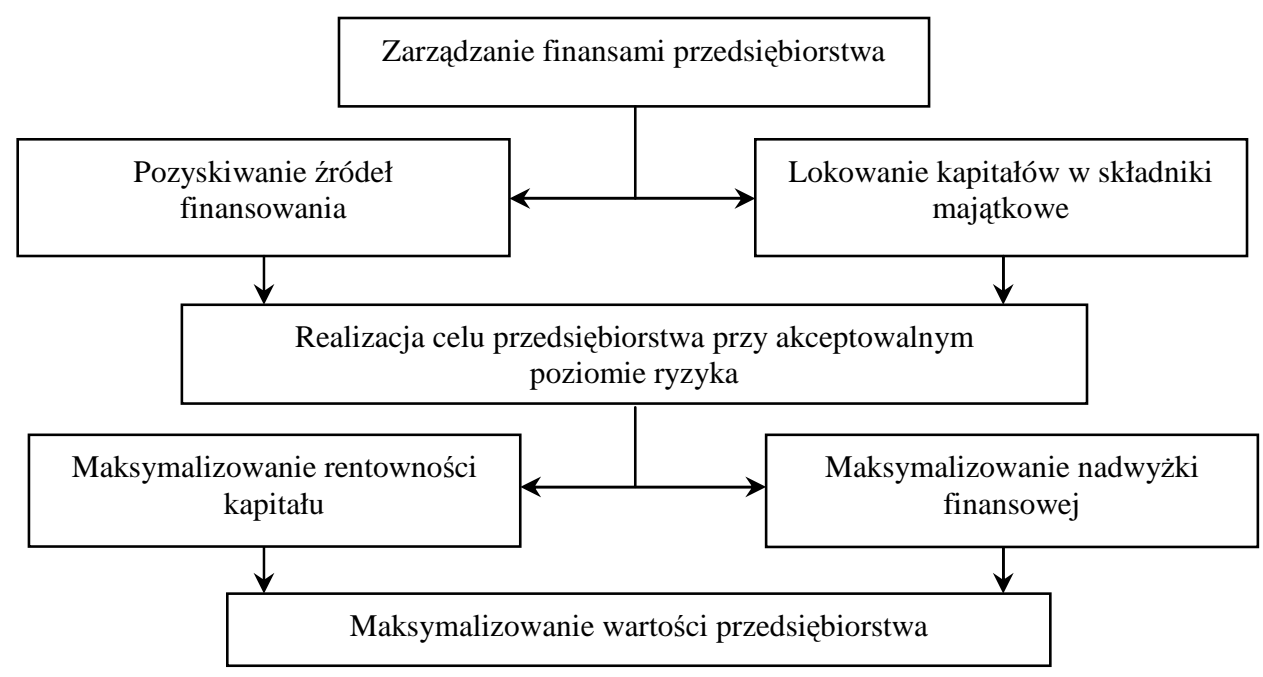

Rys. 1. Zarządzanie finansami dla wzrostu wartości przedsiębiorstwa

Źródło: opracowanie własne na podstawie: G. Goławska-Witkowska, A. Rzeczycka, H. Zalewski, Zarzadzanie finansami przedsiębiorstwa, Oficyna Wydawnicza BRANTA, Bydgoszcz 2006, s. 100.

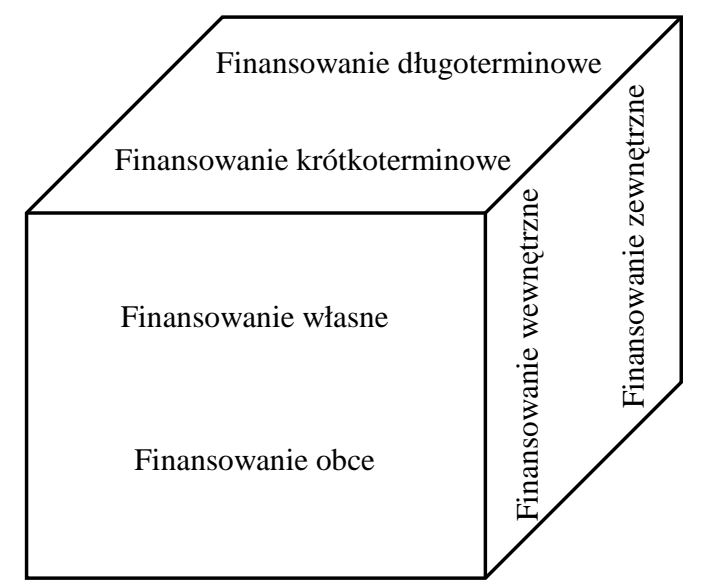

Rys. 2. Różnorodność instrumentów i metod finansowania przedsiębiorstwa Źródło: opracowanie własne.

Wielość i różnorodność uwarunkowań ekonomicznych i prawnych wymusza odpowiednią kombinację źródeł finansowania przedsiębiorstwa, które należy rozpatrywać w wielu wymiarach analitycznych. Należą do nich m. in. źródła pochodzenia kapitału, charakter własności kapitału oraz okres finansowania 
kapitału. Ta trójwymiarowa perspektywa analityczno-poznawcza wskazuje, że w praktyce zarządzania mamy do czynienia $\mathrm{z}$ wieloma kombinacjami różnorodnych instrumentów i metod finansowania przedsiębiorstwa (zob. rys. 2).

W strategiach finansowania znajdujemy wiele teorii i koncepcji, które także odnoszą się do kształtowania kapitału własnego. Jedną z nich jest teoria hierarchii źródeł finansowania. Zakłada ona, że przedsiębiorstwa preferują własne wewnętrzne źródła finansowania (kapitał samofinansowania) przedsięwzięć inwestycyjnych, zaś w dalszej kolejności korzystają z finansowania zewnętrznego ${ }^{5}$ Z $\mathrm{Z}$ tą preferencją wiążą się też problemy podwyższenia wartości kapitału zakładowego i wzrostu jego udziału w finansowaniu majątku całkowitego przedsiębiorstwa. Obie te kwestie uznane mogą być za kluczowe zmienne objaśniające rozmiary produkcji i usług, ich efektywność ekonomiczną i rentowność majątku całkowitego.

Spośród wielu cech charakterystycznych kapitału zakładowego wyszczególnić można te, które nadają jemu swoiste właściwości uwidaczniające się w tym, że kapitał ten:

- stanowi stabilne źródło finansowania oraz bazę gwarancyjną dla wierzycieli,

- posiada nieokreślony czas angażowania środków,

- poprawia płynność finansową i umożliwia terminowe regulowanie długu,

- nie posiada stałych, obligatoryjnych kosztów obsługi oraz

- ogranicza ryzyko działalności i finansowania projektów inwestycyjnych ${ }^{6}$.

Kwestia wartości kapitału zakładowego należy do bardzo ważnych problemów filozofii i praktyki finansowania przedsiębiorstwa. W realiach polskiego rynku kapitałowego, któremu często towarzyszy sytuacja niedokapitalizowania spółek, podwyższanie kapitału zakładowego może mieć szczególnie ważne znaczenie $^{7}$. Poszukiwanie zatem odpowiedzi na szereg pytań odnoszących się do jego podwyższania tworzyć może uzasadnioną perspektywę badawczą nad nie tylko nad jego przeznaczeniem, lecz także nad określeniem wpływu efektywności wykorzystania zwiększonej wartości majątku całkowitego i wartości przedsiębiorstwa na jego wzrost. Uzależnienie wzrostu wartości kapitału zakładowego od efektywności gospodarowania majątkiem całkowitym jest kwestią widzianą raczej w perspektywie pośredniego wpływu podziału określonego osiagniętego zysku netto i związania go z kapitałem zakładowym. Tego rodzaju strategia polega na kapitalizacji rezerw, która może mieć miejsce nawet w dłuższej perspektywie czasu.

${ }^{5}$ A. Duliniec, Struktura i koszt kapitatu $w$ przedsiębiorstwie, Wydawnictwo Naukowe PWN, Warszawa 2001, s. 68.

${ }^{6}$ E. O. Fi s ch e r, Finanzwirtschaft für Anfänger, 4. Auflage, Oldenbourg Wissenschaftsverlag GmbH, München 2005, s. 65.

${ }^{7}$ A. S zu mań ski, Dokapitalizowanie spótki kapitałowej, a ochrona przed jej przejęciem, PPH 1997, nr 9, s. 12. 
Proces podwyższania kapitału podstawowego przeprowadzany może być w celu tworzenia, utrzymania i powiększania składników majątkowych oraz poprawy ich optymalnego wykorzystania. Chodzi przede wszystkim o środki na finansowanie inwestycji (modernizację, zwiększenie mocy produkcyjnych, finansowanie nowoczesnych rozwiązań technologicznych itp.). Strategia ta może przyczynić się do osiagania wyższej efektywności ekonomicznej jednostki, a w dalszej kolejności do generowania dodatnich przepływów pieniężnych, które stanowią jeden z głównych nośników wartości rynkowej przedsiębiorstwa ${ }^{8}$.

Powiększony kapitał zakładowy może być wykorzystany do zmian struktury kapitału dla uzyskania optymalnej stopy zwrotu. Nadto konieczność finansowania działalności kapitałem podstawowym spółki wynikać może z chęci wzmocnienia jej stabilizacji i wiarygodności w obliczu utraty płynności finansowej, problemów z wypłacalnością bądź zagrożenia bankructwem. Zwiększenie kapitału zakładowego, w szczególności na skutek konwersji długu (np. obligacji zamiennych na akcje) pozwolić może na odzyskanie równowagi finansowej czy nawet utrzymanie się na rynku' ${ }^{9}$. W tym nurcie roli podwyższania kapitału zakładowego w finansowaniu działalności należy upatrywać nie tylko we wzroście bazy gwarancyjnej i większej wiarygodności kredytowej, ale także w podjęciu działań reorganizacyjnych, racjonalizatorskich, których efektem będzie obniżka kosztów, poprawa płynności finansowej, a w dłuższej perspektywie poprawa rentowności czy też efektywności przedsiębiorstwa.

\section{EFEKTY PODWYŻSZANIA KAPITAŁU ZAKŁADOWEGO W PUBLICZNYCH SPÓŁKACH AKCYJNYCH}

Wedle Ustawy z dnia 15 września 2000 r. - Kodeks spótek handlowych ${ }^{10}$ - kapitałem podstawowym spółki akcyjnej jest kapitał zakładowy, nazywany w literaturze niekiedy kapitałem akcyjnym ${ }^{11}$ lub wkładem właścicieli spółki

${ }^{8}$ Por. M. Michalski, Zarzqdzanie przez wartość. Firma z perspektywy interesów wtaścicielskich, WIG-Press, Warszawa 2001, s. 29-44; A. R a p p a port, Wartość dla akcjonariuszy - poradnik, WIG-Press, Warszawa 1999, s. 65; A. B lack, P. Wright, J. B achman, W poszukiwaniu wartości dla akcjonariuszy, Wydawnictwo ABC, Kraków 2000, s. 101; T. Dud y c z, Zarzqdzanie wartościq przedsiębiorstwa, PWE, Warszawa 2005, s. 24.

${ }^{9}$ Por. E. Ludwig, J. Präsch, U. S chikorra, Finanz-Management, 3. Auflage, Springer Verlag, München 2007, s. 57; J. Ic kie wi c z, op. cit., s. 66.

${ }^{10}$ Ustawa z dnia 15 września 2000 r. - Kodeks spótek handlowych [K.s.h.], DzU 2000, nr 94, poz. 1037 z późn. zm.

${ }^{11}$ Kodeks spółek handlowych ujednolicił termin „kapitał zakładowy” dla wszystkich kapitałowych spółek handlowych (spółki akcyjnej, spółki z ograniczoną odpowiedzialnościa) oraz spółek osobowych (jawnej, partnerskiej, komandytowej, komandytowo-akcyjnej), zaś w kodeksie handlowym (Rozporzqdzenie Prezydenta Rzeczypospolitej z dnia 27 czerwca 1934 r. - Kodeks handlowy, DzU 1934, nr 57, poz. 502) dla kapitału podstawowego spółki akcyjnej funkcjonował również termin ,kapitał akcyjny”. 
wnoszonym w momencie zakładania przedsiębiorstwa. Spółka akcyjna z chwilą rejestracji uzyskuje osobowość prawną, a to oznacza, że już na początku swojej działalności musi dysponować kapitałem podstawowym. Ze statutu spółki akcyjnej wynika wysokość kapitału zakładowego, sposób jego gromadzenia, nominalna wartość akcji, ich ilość oraz rodzaj (imienne, na okaziciela, zwykłe, uprzywilejowane), a także warunki i sposób umarzania akcji ${ }^{12}$. Kapitał zakładowy w spółce akcyjnej odzwierciedla nominalną wartości akcji i dzieli się na akcje o równej wartości nominalnej ${ }^{13}$. Może być wniesiony do spółki w postaci gotówki (wkłady pieniężne, czyli wpłaty na akcje) bądź aportu (wkłady niepieniężne).

Analizując gestię podwyższenia kapitału zakładowego, wskazać należy, iż niejednokrotnie termin też utożsamiany jest $\mathrm{z}$ podwyższaniem kapitału własnego przedsiębiorstwa ${ }^{14}$. Wzrost wartości kapitału zakładowego wiązać się może ze wzrostem wartości kapitału własnego, gdy źródłem jego wzrostu jest pomyślnie objęta emisja nowych akcji.

Podwyższenie kapitału zakładowego w spółce akcyjnej powoduje nie tylko zmiany struktury kapitałowej, ale wpływa także na wysokość prognozowanych przepływów pieniężnych. Dlatego sama zapowiedź podwyższenia kapitału zakładowego, zgodnie z teorią sygnalizacji, może mieć w krótkim okresie pozytywny wpływ na kształtowanie się cen akcji na rynku kapitałowym. Przeciwnie, w ujęciu długoterminowym, reakcje inwestorów mogą być odzwierciedleniem niekorzystnego efektu powiększania kapitału własnego drogą emisji nowych akcji w postaci tzw. rozwodnienia kapitału, jeżeli zwiększeniu liczby akcji nie towarzyszy proporcjonalny wzrost zysków wypracowanych przez spółkę ${ }^{15}$. Prowadzić to może do spadku współczynników rentowności, co powoduje pogorszenie efektywności przedsiębiorstwa i może stanowić o destrukcji wartości rynkowej.

Podwyższanie kapitału zakładowego w spółkach akcyjnych przyjąć może dwa następujące rodzaje ${ }^{16}$ :

a) podwyższenie efektywne, związane $\mathrm{z}$ wprowadzeniem nowych środków do spółki,

b) podwyższenie nominalne, polegające na wykorzystaniu własnych środków oraz może być przeprowadzone w czterech formach (zob. rys. 3) ${ }^{17}$.

${ }^{12}$ H. Zale w ski, Finanse firmy w spótkach i innych podmiotach gospodarczych, Wydawnictwo Ośrodka Doradztwa i Doskonalenia Kadr, Gdańsk 2000, s. 237-238.

${ }^{13}$ Zasady tworzenia i funkcjonowania spółki akcyjnej regulują art. 301-490 K.s.h.

${ }^{14} \mathrm{G}$. Wöh e, J. Bilste in, D. Ernst, J. Häcker, Grundzüge der Unternehmensfinanzierung, 10. Auflage, Vahlen Verlag, München 2011, s. 49.

${ }^{15}$ A. Dul in i e c, Struktura i koszt kapitatu..., op. cit., s. 27-28.

${ }^{16} \mathrm{G}$. Wö he, J. Bilstein, D. Ern st, J. Häcker, op. cit., s. 82.

${ }^{17}$ Szerzej: A. S ajnóg, Podwyższanie kapitału zakładowego $w$ polskich i niemieckich spótkach akcyjnych, ,Przegląd Organizacji” 2013, nr 5, s. 34-36; K.s.h, art. 430-454. 


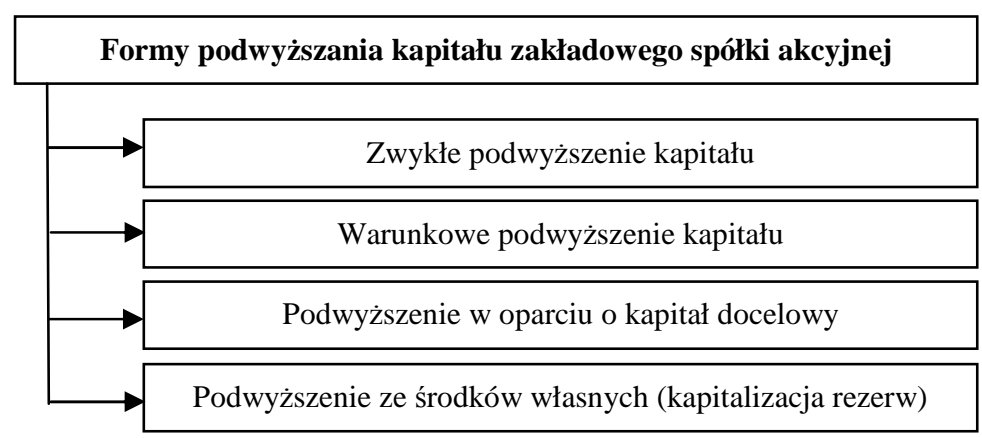

Rys. 3. Podwyższanie kapitału zakładowego spółki akcyjnej

Źródło: opracowanie własne na podstawie: K.s.h. oraz G. Eilenberger, Betriebliche Finanzwirtschaft, 7. Auflage, Oldenburg Wissenschaftsverlag GmbH, München 2003, s. 13.

Przyjmując za J. Ickiewicz, iż powszechnie stosowaną metodą podwyższania kapitału zakładowego w trybie zwykłym jest emisja nowych akcji ${ }^{18}$, wskazać można na kwestię zapewnienia pierwszeństwa poboru nowej emisji akcji dotychczasowym akcjonariuszom oraz teoretycznej wartości prawa poboru nowej emisji akcji. Wartość teoretyczna prawa poboru akcji, będącą różnicą między ceną rynkową dotychczasowych akcji danej spółki oraz ceną emisyjną nowej subskrypcji, określana jest przez stosunek subskrypcji (stosunek prawa poboru) wyrażający relację liczby dotychczasowych akcji danej spółki na rynku do liczby nowo emitowanych akcji. Powyższą relację zapisać można za pomocą następującego wzoru $^{19}$ :

$$
w_{s}=C_{r}-\frac{L_{r} \times C_{r}+L_{s} \times C_{s}}{L_{r}+L_{s}}
$$

gdzie:

$w_{s}$ - teoretyczna wartość prawa poboru akcji (wskaźnik subskrypcji),

$C_{r}$ - cena rynkowa dotychczasowych akcji,

$C_{s}$ - cena emisyjna subskrybowanych akcji,

$L_{r}$ - liczba dotychczasowych akcji na rynku oraz

$L_{s} \quad$ - liczba subskrybowanych akcji.

${ }^{18}$ J. Ic ki e w icz, Pozyskiwanie, koszt i struktura kapitału w przedsiębiorstwach, Wydawnictwo Szkoły Głównej Handlowej, Warszawa 2004, s. 98.

${ }^{19}$ E. Ludwig, J. Präsch, U. S chikorra, op. cit., s. 59. 
Po przekształceniu powyższej formuły otrzymujemy:

$$
w_{s}=\frac{C_{r}-C_{s}}{\frac{L_{r}}{L_{s}}+1}=\frac{C_{r}-C_{s}}{s_{s}+1}
$$

gdzie:

$s_{s} \quad-$ stosunek subskrypcji akcji (stosunek wymiany akcji).

Pełniejsza perspektywa wyceny teoretycznej wartości prawa poboru akcji (wskaźnik subskrypcji) zawiera również wartość oczekiwanej dywidendy płaconej od nowo subskrybowanych akcji. Tym samym teoretyczna wartość prawa poboru akcji (wskaźnik subskrypcji) jest w tym podejściu równa ${ }^{20}$ :

$$
w_{s}=\frac{C_{r}-\left(C_{s}-D_{s}\right)}{s_{s}+1}
$$

gdzie:

$D_{s}$ - dywidenda płacona od subskrybowanych akcji.

Wartość subskrypcji zależy nie tylko od cen akcji oraz stosunku ich wymiany, ale także od zainteresowania i oczekiwań poszczególnych akcjonariuszy na realizację korzyści dywidendowych. Im wyższy będzie kurs wymiany i bardziej zbliżony do ceny rynkowej akcji, tym więcej przy danym podwyższeniu kapitału zakładowego napłynie gotówki ${ }^{21}$. Z drugiej jednak strony, akcjonariusze mogą nie być zainteresowani zakupem nowych akcji ze względu na efekt tzw. rozwodnienia kapitału. Istnieje zatem potrzeba weryfikacji, czy zwykłe podwyższenie kapitału zakładowego realizowane jest w przedsiębiorstwach, w których obserwuje się pozytywne zmiany efektywności i cen rynkowych akcji wprowadzonych do obrotu publicznego w ujęciu krótko- i długoterminowym.

Prowadzone badania nad kształtowaniem się rynkowych kursów akcji spółek przeprowadzających zwykłe podwyższenie kapitału zakładowego (głównie w ramach subskrypcji otwartej) wskazuja, iż stopy zwrotu z akcji spółek przeprowadzających np. oferty publiczne są ponadprzeciętnie wysokie w krótkim terminie, natomiast $\mathrm{w}$ długim terminie są niższe od przeciętnych ${ }^{22}$. Zjawisko to

${ }^{20}$ Ibidem, s. 58.

${ }^{21}$ G. Wöh e, J. Bilste in, D. Ernst, J. Häcker, op. cit., s. 92.

${ }^{22} \mathrm{~A} . \mathrm{Al}$ a v i, P. K. Ph a m, T. M. Ph a m, Pre-IPO ownership structure and its impact on the IPO process, „Journal of Banking \& Finance” 2008, no. 32, s. 2361-2375; M. T. Billett, M. J. Flannery, J. A. Garfinkel, Frequent issuers'influence on long-run post-issuance returns, „Journal of Financial Economics” 2011, no. 99, s. 349-364; A. B rav, C. Geczy, P. A. Gompers, Is the abnormal return following equity issuances anomalous?, „Journal of 
nie zostało jednak dotychczas wystarczająco opisane i wyjaśnione w warunkach polskiego rynku giełdowego.

Analiza światowej literatury przedmiotu wskazuje ponadto, iż po przeprowadzeniu publicznych ofert sprzedaży akcji można oczekiwać pogorszenia kondycji finansowej przedsiębiorstw, których akcje zostały wprowadzone do publicznego obrotu. Wyniki badań empirycznych prowadzonych na zagranicznych rynkach finansowych zdają się potwierdzać tak sformułowaną hipotezę ${ }^{23}$. Na polskim rynku kapitałowym zjawisko to dotychczas nie zostało w wystarczającym stopniu rozpoznane.

Podkreślić należy - za A. Duliniec - że praktyka przedsiębiorstw funkcjonujących na rozwiniętych rynkach finansowych zauważa jedno z głównych źródeł finansowania działalności bieżącej i rozwojowej przedsiębiorstwa, jaki są zyski zatrzymane ${ }^{24}$. Kapitał samofinansowania i kapitalizacja zysku netto (zatrzymywanie zysku) stanowią bardzo ważne wewnętrzne źródło finansowania, z jakiego korzystają przedsiębiorstwa. Teoretycznie stanowić to może o potencjale wykorzystania nominalnego podwyższania kapitału zakładowego w formie kapitalizacji rezerw. Z drugiej jednak strony, ,papierowe” podwyższenie kapitału zakładowego, na skutek braku pozyskania środków z zewnątrz, nie realizuje celów inwestycyjnych. Akcjonariusze spółki mogą być zatem mniej zainteresowani takim trybem powiększania kapitału zakładowego.

Wskazać można, iż proces kapitalizacji rezerw jest wyrazem wzmacniania zachowawczej polityki finansowej przedsiębiorstwa, które w krótkim okresie nie widzi możliwości zainwestowania nadwyżek finansowych, co może przyczynić się do niekorzystnych zmian efektywności spółki i rynkowych cen jej akcji. W ujęciu długoterminowym zaś, polityka kapitalizacji rezerw może być odczytana jako pozytywna sytuacja finansowa przedsiębiorstwa. Celem nominalnego zwiększania kapitału zakładowego w ujęciu długoterminowym może być

Financial Economics" 2000, no. 56, s. 209-249; M. J. B rennan, J. Franks, Underpricing, ownership and control in initial public offerings of equity securities in the UK, ,Journal of Financial Economics" 1997, no. 45, s. 391-413; A. Ljungqvist, IPO underpricing, [w:] B. E. Eckbo (red.), Handbook of Corporate Finance: Empirical Corporate Finance, 2006, vol. A, chapter 7; W. J. M c N ally, B. F. S mit h, Long-run returns following open market share repurchases, „Journal of Banking \& Finance” 2007, no. 31, s. 703-717; D. S u k a c z, Pierwsze oferty publiczne na rynkach kapitatowych, CeDeWu.pl, Warszawa 2005.

${ }^{23}$ Por. S. T e o h, I. W e l c h, T. W on g, Earnings management and the long-run market performance of initial public offerings, „Journal of Finance” 1998, no. 53, s. 1935-1974; M. Pa g a no, F. P a e t t a, L. Zing ales, Why do companies go public? An empirical analysis, „Journal of Finance” 1998, no. 53, s. 27-64; A. K hu rs h e d, Initial public offerings. An analysis of the post-IPO performance of UK firms. Unpublished PhD thesis, University of Reading, 1999; J. C a i, C. J. W e i, The investment and operating performance of Japanese initial public offerings, „Pacific-Basin Finance Journal” 1997, no. 5, s. 389-417.

${ }^{24}$ A. Duliniec, Struktura $i$ koszt kapitatu..., op. cit., s. 36-37, S. A. Ross, R. W. Westerfield, J. Jaffe, Corporate Finance, Irwin, Chicago 1996, s. 379; R. A. Brealey, S. C. Myers, A. J. Marcus, Fundamentals of Corporate Finance, McGraw-Hill, New York 1995, s. 400-401. 
wzmocnienie wiarygodności spółki poprzez osiągnięcie większych gwarancji majątkowych. W przeciwieństwie do kolejnych emisji akcji na rynku (które mogą stanowić negatywny sygnał dla inwestorów), w konsekwencji kapitalizacji rezerw, mimo zwiększenia liczby akcji posiadanych przez akcjonariuszy, nie ulega zmianie ich procentowy udział w kapitale zakładowym. Tym samym nie powoduje to efektu rozwodnienia kapitału własnego.

Przeprowadzone na rynku niemieckim fragmentaryczne wyniki badań potwierdzają pozytywną reakcję rynku na podwyższenie kapitału zakładowego ze środków własnych spółki, a co ważne obserwuje się spadek długoterminowej rentowności po takiej zmianie ${ }^{25}$. Na podstawie wstępnie poczynionych badań na rynku polskim można z kolei wskazać, iż:

- po podjęciu decyzji o kapitalizacji rezerw, w większości przypadków notuje się pozytywne zmiany wartości rynkowej w ujęciu krótkoterminowym, z kolei długookresowe zmiany wartości nie mają już tak pozytywnego charakte$\mathrm{ru}^{26}$ oraz

- w większości przypadków po przeprowadzeniu podwyższania kapitału zakładowego ze środków własnych zmiany rentowności kapitału własnego oraz rentowności aktywów całkowitych mają negatywny charakter ${ }^{27}$.

Rezultaty przeprowadzonych analiz stanowić mogą zasadniczą podstawę do rozszerzenia dotychczasowych wyników badań nad oceną wrażliwości efektywności i wartości na podwyższenie kapitału zakładowego.

\section{WYNIKI BADAŃ EMPIRYCZNYCH WYBRANYCH SPÓŁEK BUDOWLANYCH}

Dla potrzeb analizy roli i znaczenia podwyższania kapitału zakładowego w kształtowaniu efektywności i wartości przedsiębiorstw, badaniami empirycznymi został objęty sektor budownictwo ${ }^{28}$, w którym odnotowano największą liczbę spółek notowanych na GPW w Warszawie w latach 2003-2012. Spośród 35 spółek zakwalifikowanych do tej branży, do badań wyodrębnione zostały te, w których dane liczbowe (w tym notowania rynkowe) były dostępne za cały dziesięcioletni okres. Tym samym wstępnej analizie poddano 18 spółek budowlanych.

${ }^{25}$ G. Wöh e, J. Bilste in, D. Ernst, J. Häcker, op. cit., s. 316.

${ }^{26}$ A. Sajnóg, Kapitalizacja rezerw a kreowanie wartości giełdowych spótek akcyjnych, „Acta Universitatis Lodziensis”, Folia Oeconomica, Wydawnictwo Uniwersytetu Łódzkiego (w druku).

${ }^{27}$ A. S a j nóg, Wptyw kapitalizacji rezerw na dtugookresowq rentowność publicznych spótek giełdowych, „Prace Naukowe Uniwersytetu Ekonomicznego we Wrocławiu” (w druku).

28 Podział został zaczerpnięty z bazy danych Notoria Serwis SA (http://ir.notoria.pl) oraz Giełdy Papierów Wartościowych w Warszawie (http://www.gpw.pl; http://www.gpwinfostrefa.pl). 
Procedura badawcza została zrealizowana w dwóch częściach. W pierwszej części znajdują się wyniki badań empirycznych nad zmianami kapitału zakładowego badanych spółek, zaś część druga zawiera wyniki badań nad relacjami między kształtowaniem się kapitału zakładowego oraz jego udziału w kapitale własnym i majątku całkowitym a wybranymi miernikami efektywności i wartości spółek budowlanych podwyższających kapitał zakładowy. Biorąc pod uwagę tak postawiony cel, wykluczono z analizy te spółki, które w badanym dziesięcioleciu nie podwyższały kapitału zakładowego. Ostatecznie, szczegółowym badaniem zależności pomiędzy badanymi kategoriami objęto 14 spółek budowlanych.

Badania empiryczne zostały oparte na sprawozdaniach finansowych prezentowanych przez Notoria Serwis SA, danych pochodzących ze stron internetowych spółek oraz portali giełdowych.

\subsection{Analiza zmian kapitału zakładowego $w$ badanych spółkach budowlanych}

Na podstawie zaprezentowanych na rys. 3. wyników badań empirycznych stwierdzić należy, iż w badanym okresie średnia wartość księgowa kapitału zakładowego badanych jednostek wykazała tendencję rosnącą - od około $17 \mathrm{mln}$ zł w 2003 r. do ponad $45 \mathrm{mln}$ zł w ostatnim badanym okresie (zob. rys. 4).

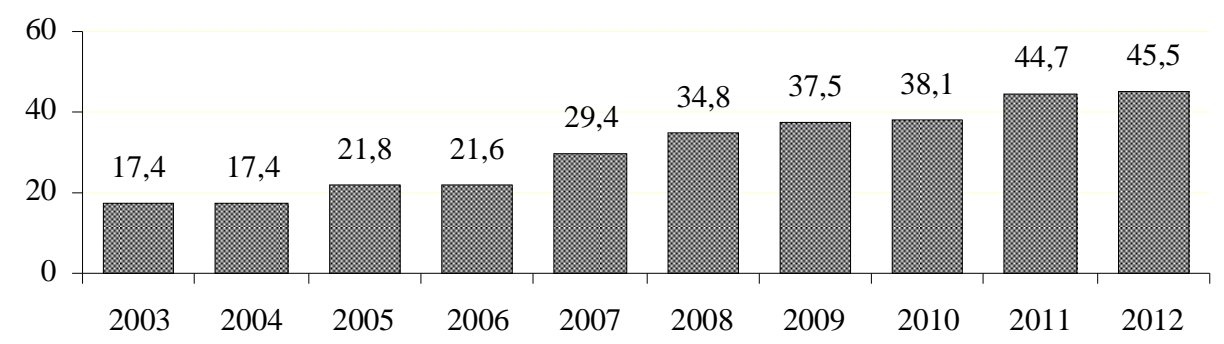

Rys. 4. Średnie wartości kapitału zakładowego badanych spółek budowlanych w latach 2003-2012

Źródło: opracowanie własne na podstawie bazy danych Notoria Serwis SA.

Największe pozytywne zmiany w kształtowaniu wartości kapitału zakładowego w badanym dziesięcioleciu odnotowano w 2006 r. Na podstawie obliczonego średniego wskaźnika dynamiki tego kapitału wskazać można, iż w 2006 r. nastąpił wzrost wartości kapitału zakładowego o ponad $60 \%$ w stosunku do roku poprzedniego. Równie znaczne i korzystne zmiany po stronie wartości omawianego kapitału nastąpiły w latach: 2004, 2007, 2008 i 2010 (zob. tab. 1).

W niektórych badanych spółkach prowadzona była tzw. neutralna polityka kształtowania kapitału zakładowego, której wyrazem było utrzymanie na do- 
tychczasowym poziomie wartości kapitału zakładowego. Taką zachowawczą strategię stosowały trzy spółki: Budimex SA, Instal Kraków SA oraz Mostostal Płock SA.

Tabela 1

Dynamika wartości kapitału zakładowego w badanych spółkach budowlanych w latach 2003-2012 (rok poprzedni $=100)$

\begin{tabular}{|l|r|r|r|r|r|r|r|r|r|r|}
\hline \multicolumn{1}{|c|}{ Spółki akcyjne } & 2003 & 2004 & 2005 & 2006 & 2007 & 2008 & 2009 & 2010 & 2011 & 2012 \\
\hline \hline Awbud & 100,0 & 100,0 & 100,0 & 100,0 & 100,0 & 100,0 & 255,1 & 546,9 & 97,3 & 100,0 \\
\hline Budimex & 100,0 & 100,0 & 100,0 & 100,0 & 100,0 & 100,0 & 100,0 & 100,0 & 100,0 & 100,0 \\
\hline Budopol-Wrocław & 100,0 & 100,0 & 100,0 & 577,8 & 100,0 & 200,0 & 100,0 & 100,0 & 100,0 & 100,0 \\
\hline CNT & 100,0 & 100,0 & 100,0 & 100,0 & 500,0 & 100,0 & 100,0 & 100,0 & 100,0 & 81,9 \\
\hline Elektrobudowa & 100,0 & 293,7 & 100,0 & 102,0 & 100,0 & 104,2 & 100,0 & 100,0 & 100,0 & 100,0 \\
\hline Elkop & 100,0 & 100,0 & 100,0 & 100,0 & 200,0 & 548,7 & 100,0 & 100,0 & 194,0 & 154,7 \\
\hline Energoaparatura & 100,0 & 100,0 & 100,0 & 100,0 & 124,7 & 105,2 & 100,0 & 100,0 & 100,0 & 100,0 \\
\hline Energomontaż-Płd. & 100,0 & 294,0 & 100,0 & 100,0 & 202,1 & 106,7 & 100,0 & 132,4 & 100,0 & 100,0 \\
\hline Instal Kraków & 100,0 & 100,0 & 100,0 & 100,0 & 100,0 & 100,0 & 100,0 & 100,0 & 100,0 & 100,0 \\
\hline Mostostal-Export & 99,5 & 174,3 & 100,0 & 100,0 & 100,0 & 100,0 & 100,0 & 100,0 & 100,0 & 100,0 \\
\hline Mostostal Płock & 100,0 & 100,0 & 100,0 & 100,0 & 100,0 & 100,0 & 100,0 & 100,0 & 100,0 & 100,0 \\
\hline Mostostal Warszawa & 100,0 & 100,0 & 100,0 & 200,0 & 100,0 & 100,0 & 100,0 & 224,0 & 100,0 & 100,0 \\
\hline Mostostal Zabrze & 100,0 & 100,0 & 100,0 & 632,5 & 116,0 & 100,0 & 100,0 & 100,0 & 100,0 & 100,0 \\
\hline Pemug & 100,0 & 100,0 & 100,0 & 100,0 & 106,3 & 123,5 & 100,0 & 100,0 & 100,0 & 100,0 \\
\hline Polimex-Mostostal & 100,0 & 193,2 & 82,2 & 100,0 & 121,8 & 100,0 & 100,0 & 112,2 & 100,0 & 100,0 \\
\hline Prochem & 89,3 & 91,7 & 99,7 & 100,0 & 100,0 & 99,9 & 100,0 & 99,9 & 100,0 & 100,0 \\
\hline Projprzem & 98,4 & 99,9 & 100,0 & 100,0 & 133,3 & 100,0 & 100,0 & 100,0 & 100,0 & 100,0 \\
\hline Ulma & 110,5 & 100,0 & 100,0 & 100,0 & 107,5 & 100,0 & 100,0 & 100,0 & 100,0 & 100,0 \\
\hline \hline Średnia & 99,9 & 130,4 & 99,0 & 161,8 & 139,5 & 132,7 & 108,6 & 134,2 & 105,1 & 102,0 \\
\hline
\end{tabular}

W tabeli wyróżniono pogrubioną czcionką te spółki, które nie przeprowadziły podwyższenia kapitału zakładowego w badanym dziesięcioleciu.

Źródło: opracowanie własne na podstawie bazy danych Notoria Serwis SA.

Przeprowadzona analiza dynamiki kapitału zakładowego spółki Mostostal-Export SA wskazała co prawda na pozytywne zmiany wartości księgowej tego kapitału w 2004 r. w stosunku do roku poprzedniego, jednakże były one spowodowane wyłącznie przyjęciem przez spółkę innych zasad rachunkowości (nie wedle polskich przepisów ustawy o rachunkowości, ale na podstawie $\operatorname{MSSF}^{29}$ ).

${ }^{29}$ Według MSSF (Międzynarodowych Standardów Sprawozdawczości Finansowej), spółki wykazują w sprawozdaniach kapitał podstawowy, który jest kategorią szerszą aniżeli kapitał zakładowy zgody z polskimi przepisami o rachunkowości. 
Można zatem uznać, iż w jej przypadku nie przeprowadzono procesu podwyższenia kapitału zakładowego.

Dla potrzeb analizy określonej strategii finansowania badanych spółek, która skupia się na wzroście zaangażowania kapitału zakładowego w finansowanie majątku całkowitego oraz może przyczyniać się do wzrostu efektywności i wartości przedsiębiorstwa, obliczono stopień finansowania majątku całkowitego przez kapitał zakładowy za pomocą następującej formuły:

$$
S C T A=S C / T A \times 100
$$

gdzie:

SCTA (ang. share capital to assets ratio) - współczynnik udziału kapitału zakładowego w finansowaniu majątku całkowitego,

$S C$ (ang. share capital) - wartość księgowa kapitału zakładowego,

TA (ang. total assets) - wartość księgowa aktywów ogółem.

Tabela 2

Wartości współczynników SCTA w badanych spółkach budowlanych w latach 2003-2012 (w \%)

\begin{tabular}{|l|r|r|r|r|r|r|r|r|r|r||c|}
\hline \multicolumn{1}{|c|}{ Spółki akcyjne } & 2003 & 2004 & 2005 & 2006 & 2007 & 2008 & 2009 & 2010 & 2011 & 2012 & Średnia \\
\hline \hline Awbud & 15 & 20 & 29 & 23 & 20 & 18 & 15 & 26 & 25 & 34 & 25,8 \\
\hline Budopol-Wrocław & 22 & 41 & 42 & 63 & 121 & 94 & 73 & 69 & 71 & 62 & 77,5 \\
\hline CNT & 22 & 26 & 27 & 31 & 24 & 55 & 53 & 51 & 33 & 48 & 38,3 \\
\hline Elektrobudowa & 5 & 5 & 15 & 15 & 10 & 8 & 6 & 6 & 5 & 4 & 7,6 \\
\hline Elkop & 11 & 13 & 15 & 22 & 21 & 35 & 105 & 111 & 132 & 145 & 68,8 \\
\hline Energoaparatura & 16 & 13 & 20 & 23 & 20 & 23 & 18 & 17 & 19 & 15 & 18,1 \\
\hline Energomontaż-Płd. & 12 & 11 & 34 & 32 & 28 & 34 & 24 & 16 & 22 & 24 & 32,1 \\
\hline Mostostal Warszawa & 4 & 4 & 5 & 6 & 5 & 3 & 3 & 2 & 4 & 3 & 3,9 \\
\hline Mostostal Zabrze & 9 & 12 & 13 & 17 & 58 & 81 & 65 & 57 & 41 & 50 & 44,7 \\
\hline Pemug & 23 & 23 & 22 & 23 & 21 & 26 & 27 & 26 & 26 & 28 & 25,7 \\
\hline Polimex-Mostostal & 3 & 3 & 2 & 2 & 1 & 1 & 1 & 1 & 1 & 1 & 1,3 \\
\hline Prochem & 7 & 8 & 2 & 2 & 3 & 2 & 2 & 4 & 4 & 3 & 3,1 \\
\hline Projprzem & 12 & 11 & 11 & 8 & 7 & 5 & 4 & 4 & 5 & 5 & 6,4 \\
\hline Ulma & 8 & 10 & 9 & 6 & 4 & 3 & 2 & 2 & 2 & 2 & 4,2 \\
\hline \hline Średnia & 12,0 & 14,3 & 17,6 & 19,3 & 24,4 & 27,6 & 28,4 & 28,0 & 27,7 & 30,3 & $\mathrm{x}$ \\
\hline
\end{tabular}

Źródło: jak do tab. 1.

Analizując obliczone średnie wartości współczynników udziału kapitału zakładowego w finansowaniu majątku całkowitego (SCTA) w badanym dziesięcioleciu, stwierdzić można, iż stopień pokrycia aktywów całkowitych przez kapitał 
zakładowy wykazywał w większości analizowanych okresów tendencję rosnącą i wzrósł - od 14,3\% w 2003 r. do 37,8\% w ostatnim badanym okresie (zob. tab. 2). Zwrócić należy uwagę, iż w latach 2008-2010 zaobserwowano nieznaczny spadek udziału kapitału zakładowego w finansowaniu działalności badanych spółek.

Na podstawie wyników badań empirycznych stwierdzić można, iż najwyższym stopniem finansowania majątku przez kapitał zakładowy wykazały się spółki: Budopol Wrocław SA oraz Elkop SA, gdyż w badanym dziesięcioleciu średnia wartość udziału kapitału zakładowego w finansowaniu aktywów całkowitych wyniosła odpowiednio około $78 \%$ oraz $69 \%$. Najniższy stopień wykorzystania kapitału podstawowego w finansowaniu majątku zaobserwowano w spółce Polimex-Mostostal.

Po podwyższeniu kapitału zakładowego następuje również zmiana struktury kapitału własnego przedsiębiorstwa, która może pozytywnie bądź negatywnie oddziaływać na efektywność ekonomiczną oraz wartość rynkową spółki giełdowej.

W analizie udziału kapitału zakładowego w kapitale własnym, który można zastosować następującą formułę:

$$
S C E=S C / E \times 100
$$

gdzie:

SCE (ang. share capital to equity ratio) - współczynnik udziału kapitału zakładowego w kapitale własnym,

$E$ (ang. equity) - wartość księgowa kapitału własnego,

pozostałe oznaczenia jak wyżej.

Powyższy wskaźnik jest odwrotnością wskaźnika obrazującego strukturę kapitału własnego, określanego w literaturze mianem współczynnika kursu bilansowego ${ }^{30}$.

Na podstawie wyników badań empirycznych stwierdzić można, iż najniższym stopniem wyposażenia kapitału własnego w kapitał zakładowy wykazały się dwie spółki: Pemug SA oraz Prochem SA, gdyż w badanym dziesięcioleciu średnia wartość udziału kapitału zakładowego w kapitale własnym wyniosła około $7,4 \%$ (zob. tab. 3 ).

Oceniając udział kapitału zakładowego w kapitale własnym badanych spółek budowlanych w latach 2003-2012, wskazać można na kilka nietypowych wartości miar SCE, związanych z kształtowaniem się wartości księgowej kapitału własnego. W szczególności na uwagę zasługuje fakt, iż w sprawozdaniach finansowych pięciu spółek odnotowano przypadki ujemnego kapitału własnego.

${ }^{30}$ J. O s t a s zew s ki, T. Ci c ir k o, Finanse spótki akcyjnej, Difin, Warszawa 2005, s. 104. 
Sytuacja ta dotyczyła:

- spółki Budopol-Wrocław w latach 2003-2005,

- spółki Elkop w latach 2004-2006,

- spółki Mostostal Warszawa w latach 2003-2005,

- spółki Projprzem w 2003 r. oraz

- spółki Elektrobudowa w latach 2005-2007.

Tabela 3

Wartości współczynników SCE w badanych spółkach budowlanych w latach 2003-2012 (w \%)

\begin{tabular}{|l|r|r|r|r|r|r|r|r|r|r||r|}
\hline Spółki akcyjne & 2003 & 2004 & 2005 & 2006 & 2007 & 2008 & 2009 & 2010 & 2011 & 2012 & Srednia \\
\hline \hline Awbud & 61 & 280 & 78 & 76 & 64 & 52 & 40 & 33 & 53 & 108 & 85 \\
\hline $\begin{array}{l}\text { Budopol- } \\
\text {-Wrocław }\end{array}$ & -1793 & -317 & -127 & 194 & 173 & 110 & 103 & 94 & 82 & 211 & -127 \\
\hline CNT & 24 & 20 & 18 & 21 & 48 & 41 & 25 & 37 & 46 & 74 & 35 \\
\hline Elektrobudowa & 473 & 3639 & -2155 & -1672 & -4724 & 179 & 224 & 269 & 118 & 8 & -364 \\
\hline Elkop & 49 & -33 & -36 & -41 & 54 & 240 & 181 & 149 & 266 & 97 & 93 \\
\hline Energoaparatura & 16 & 14 & 14 & 12 & 6 & 8 & 7 & 6 & 9 & 27 & 12 \\
\hline $\begin{array}{l}\text { Energomontaż- } \\
\text {-Płd. }\end{array}$ & 25 & 73 & 61 & 58 & 90 & 75 & 62 & 72 & 62 & -36 & 54 \\
\hline $\begin{array}{l}\text { Mostostal } \\
\text { Warszawa }\end{array}$ & -14 & -14 & -9 & 22 & 15 & 13 & 12 & 26 & 27 & 34 & 1 \\
\hline Mostostal Zabrze & 58 & 14 & 12 & 38 & 21 & 20 & 14 & 13 & 12 & 96 & 30 \\
\hline Pemug & 9 & 5 & 4 & 3 & 1 & 1 & 2 & 1 & 1 & 47 & 7 \\
\hline Polimex- \\
-Mostostal
\end{tabular}

Źródło: jak do tab. 1.

Najbardziej nietypowe wartości pojawiły się w ostatniej z wymienionych spółek, na skutek znacznego podwyższenia kapitału zakładowego w 2004 r. w stosunku do roku poprzedniego (por. tab. 1), przy jednoczesnym zmniejszeniu wartości księgowej kapitału własnego. Świadczą o tym obliczone współczynniki SCE w latach 2004-2007, które kształtowały się od 3639\% do nawet $-4724 \%$.

\subsection{Ocena zależności między podwyższaniem kapitału zakładowego a efektywnością i wartością spółek budowlanych}

Analiza wpływu podwyższenia kapitału zakładowego na kształtowanie efektywności oraz wartości badanych spółek budowlanych skoncentrowana została na ocenie zależności między wybranymi miernikami dotyczącymi zmian 
wartości księgowej kapitału zakładowego a wybranymi wskaźnikami efektywności i wartości analizowanych jednostek.

Odnosząc się do zmian po stronie kapitału własnego badanych spółek, posłużono się trzema wskaźnikami - dynamiki kapitału zakładowego, udziału kapitału zakładowego w kapitale własnym ( $S C E)$ oraz stopnia finansowania majątku całkowitego kapitałem zakładowym (SCTA). W stosunku do kategorii efektywnościowych, przyjęto typowe miary rentowności aktywów całkowitych ROTA (ang. return on total assets ratio) oraz rentowności kapitału własnego ROE (ang. return on equity ratio). Z kolei spośród wielu mierników wartości rynkowej spółek wybrane zostały dwa wskaźniki - kapitalizacja rynkowa $(K A P)$ oraz cena do wartości księgowej $(C / W K)$. Ich wybór podyktowany był dostępnością owych danych, gdyż są one publikowane w biuletynach GPW w Warszawie. Celowo został jednakże pominięty wskaźnik $C / Z$, gdyż na skutek znacznej deficytowości badanych spółek, dość często nie był on prezentowany ${ }^{31}$.

Wyniki badań empirycznych potwierdzają pewne zróżnicowanie mierników efektywności i wartości analizowanych spółek w badanym dziesięcioleciu. Bazując na wartościach średnich, podkreślić należy występującą deficytowość analizowanych jednostek (liczne okresy badawcze, w których spółki generowały straty finansowe) bądź deprecjację rentowności na skutek ujemnej wartości kapitału własnego (zob. tab. 4).

Tabela 4

Średnie wartości mierników ROTA, ROE, KAP, C/WK badanych spółek budowlanych w latach 2003-2012

\begin{tabular}{|c|c|r|r|r|r|r|r|r|r|r|r|}
\hline \multicolumn{2}{|c|}{ Mierniki } & 2003 & 2004 & 2005 & 2006 & 2007 & 2008 & 2009 & 2010 & 2011 & 2012 \\
\hline \hline \multirow{2}{*}{ ROTA } & \multirow{2}{*}{ w \% } & $-6,2$ & $-3,0$ & $-1,4$ & 5,2 & 7,4 & 3,5 & 2,6 & 1,0 & 0,8 & $-13,1$ \\
\cline { 1 - 11 } ROE & 12,1 & 10,7 & $-235,2$ & $-60,8$ & $-214,7$ & 77,9 & 55,3 & 38,9 & 18,9 & $-156,5$ \\
\hline KAP & w mln zł & 32 & 76 & 122 & 427 & 695 & 305 & 394 & 402 & 195 & 130 \\
\hline C/WK & - & 0,9 & 1,1 & 1,7 & 10,1 & 15,2 & 1,7 & 1,8 & 1,6 & 0,9 & 0,7 \\
\hline
\end{tabular}

Źródło: opracowanie własne na podstawie bazy danych Notoria Serwis SA oraz rocznych biuletynów giełdowych GPW w Warszawie.

Na podstawie wyników badań empirycznych stwierdzić można, iż najwyższe wartości mierników rynkowych $(K A P$ oraz $C / W K)$ odnotowano w latach 2006-2007, które generalnie potwierdzają okresy znacznego ożywienia giełdowego. Może znaleźć to swoje odzwierciedlenie we wpływie podwyższania kapitału zakładowego na efektywność i wartość badanych jednostek.

31 W biuletynach giełdowych praktykuje się wówczas bądź nieprezentowanie w ogóle wskaźnika bądź podawanie jego zerowej wartości. 
Mając na względzie cztery miary efektywnościowo-wartościowe oraz trzy wskaźniki opisujące zmiany kapitału zakładowego, stworzone zostały cztery modele jednorównaniowe (cztery zmienne objaśniane) z trzema zmiennymi objaśniającymi. Postać funkcyjna modelu opisującego wpływ podwyższania kapitału zakładowego na efektywność ekonomiczną i wartość badanych jednostek opierała się na tempach wzrostu zarówno zmiennych endogenicznych, jak i zmiennych egzogenicznych. Tempo wzrostu zostało zdefiniowane w następujący sposób:

$$
i^{\circ}=\frac{i_{t+1}-i_{t}}{i_{t}}
$$

gdzie:

$i^{\circ} \quad-$ tempo wzrostu zmiennej $i$,

$i_{t+1}-$ wartość zmiennej $i$ w okresie $t+1$,

$i_{t} \quad-$ wartość zmiennej $i$ w okresie $t$.

Jednoczesne badanie czterech modeli, zapisanych analitycznie w tab. 5, umożliwiło ocenę porównawczą efektów zwiększania wartości księgowej kapitału zakładowego, w podziale na efektywność i wartość analizowanych spółek budowlanych.

Postać analityczna modeli opisujących wpływ zmian kapitału zakładowego na efektywność i wartość badanych spółek budowlanych

\begin{tabular}{|c|c|c|}
\hline \multicolumn{2}{|c|}{ Wersja modelu } & Postać analityczna \\
\hline \hline \multirow{2}{*}{ „Efektywnościowa” } & Model 1 & $R O T A^{\circ}=f\left(S C^{\circ}, S C T A^{\circ}, S C E^{\circ}\right)$ \\
& Model 2 & $R O E^{\circ}=f\left(S C^{\circ}, S C T A^{\circ}, S C E^{\circ}\right)$ \\
\hline \multirow{2}{*}{ „Wartościowa" } & Model 3 & $K A P^{\circ}=f\left(S C^{\circ}, S C T A^{\circ}, S C E^{\circ}\right)$ \\
\cline { 2 - 3 } & Model 4 & $C / W K^{\circ}=f\left(S C^{\circ}, S C T A^{\circ}, S C E^{\circ}\right)$ \\
\hline
\end{tabular}

Źródło: opracowanie własne.

Metodą badawczą zastosowaną w opracowaniu stała się analiza regresji ${ }^{32}$. W badaniu przyjęto warunki konieczne niezbędne do wyznaczenia parametrów modelu stojących przy zmiennych egzogenicznych z użyciem metody najmniejszych kwadratów, tj. założono, iż rozkład składnika losowego jest normalny, nie

${ }^{32} \mathrm{~W}$ badaniu posłużono się średnimi wartościami zmiennych endogenicznych oraz egzogenicznych w analizowanych spółkach. 
występuje autokorelacja składnika losowego a jego wariancja jest stała. Ponadto stwierdzono brak silnej korelacji między zmiennymi objaśniającymi ${ }^{33}$. Weryfikacja istotności omawianych parametrów funkcji regresji została przeprowadzona $\mathrm{w}$ oparciu o statystykę testu $t$-Studenta. Prawdopodobieństwo popełnienia błędu pierwszego rodzaju przyjęto na poziomie $5 \%$.

Analizując powyższe modele od strony merytorycznej, zwrócić należy uwagę na kierunki wpływu zmiennych egzogenicznych na zmienną endogeniczna. Z tego punktu widzenia owe kierunki wpływu zmian kapitału zakładowego na efektywność i wartość spółek budowlanych okazały się zróżnicowane (zob. tab. 6).

Tabela 6

Wyniki estymacji modeli opisujących wpływ zmian kapitału zakładowego na efektywność i wartość badanych spółek budowlanych

\begin{tabular}{|c|c|c|c|c|c|c|c|}
\hline $\begin{array}{l}\text { Wersja } \\
\text { modelu }\end{array}$ & $\begin{array}{c}\text { Zmienna } \\
\text { endoge- } \\
\text { niczna }\end{array}$ & $\begin{array}{c}\text { Zmienna } \\
\text { egzoge- } \\
\text { niczna }\end{array}$ & $\begin{array}{l}\text { Wartości } \\
\text { parame- } \\
\text { trów }\end{array}$ & $\begin{array}{l}\text { Statysty- } \\
\text { ka } t\end{array}$ & $\begin{array}{l}\text { Poziom } \\
\text { istotności } \\
\text { testu }\end{array}$ & $\begin{array}{c}\text { Wartość } \\
\text { krytyczna } \\
t_{\infty} \text { w przy- } \\
\text { padku, gdy } \\
\alpha=0,05\end{array}$ & $\begin{array}{c}\text { Współ- } \\
\text { czynnik } \\
\text { determina- } \\
\text { cji } R^{2}\end{array}$ \\
\hline \multirow{3}{*}{$\begin{array}{c}\text { Model } \\
1\end{array}$} & \multirow{3}{*}{$R^{\prime} O T A^{\circ}$} & $S C^{\circ}$ & $-0,19$ & $-0,34$ & 0,75 & \multirow{12}{*}{2,31} & \multirow{3}{*}{0,68} \\
\hline & & $S C T A^{\circ}$ & 1,67 & 1,12 & 0,31 & & \\
\hline & & $S C E^{\circ}$ & $-0,39$ & $-3,58$ & $\mathbf{0 , 0 1}$ & & \\
\hline \multirow{3}{*}{$\begin{array}{l}\text { Model } \\
2\end{array}$} & \multirow{3}{*}{$R O E^{\circ}$} & $S C^{\circ}$ & 2,04 & 0,76 & 0,48 & & \multirow{3}{*}{0,35} \\
\hline & & $S C T A^{\circ}$ & $-10,72$ & $-1,49$ & 0,19 & & \\
\hline & & $S C E^{\circ}$ & 0,04 & 0,09 & 0,93 & & \\
\hline \multirow{3}{*}{$\begin{array}{c}\text { Model } \\
3\end{array}$} & \multirow{3}{*}{$K A P^{\circ}$} & $S C^{\circ}$ & 2,74 & 1,89 & 0,11 & & \multirow{3}{*}{0,46} \\
\hline & & $S C T A^{\circ}$ & 3,26 & 0,84 & 0,43 & & \\
\hline & & $S C E^{\circ}$ & $-0,24$ & $-0,88$ & 0,41 & & \\
\hline \multirow{3}{*}{$\begin{array}{c}\text { Model } \\
4\end{array}$} & \multirow{3}{*}{$C / W K^{\circ}$} & $S C^{\circ}$ & 0,31 & 0,21 & 0,84 & & \multirow{3}{*}{0,15} \\
\hline & & $S C T A^{\circ}$ & 3,92 & 0,98 & 0,36 & & \\
\hline & & $S C E^{\circ}$ & $-0,17$ & $-0,58$ & 0,58 & & \\
\hline
\end{tabular}

W tabeli pogrubioną czcionką wyróżniono istotne statystycznie zmienne egzogeniczne.

Źródło: opracowanie własne na podstawie pakietu Statistica 10.

Najbardziej pejoratywny wpływ na kategorie efektywnościowo-wartościowe miało tempo wzrostu udziału kapitału zakładowego w kapitale własnym. Świadczą o tym ujemne wartości oszacowanych parametrów strukturalnych w trzech spośród czterech modeli. W szczególności podkreślić trzeba, iż wy-

${ }^{33}$ Posłużono się w tym celu analizą korelacji z wykorzystaniem współczynnika korelacji rang Spearmana. 
łącznie przy tej zmiennej stwierdzono istotność statystyczną w modelu o zmiennej endogenicznej w postaci tempa rentowności majątku całkowitego. Z kolei najbardziej pozytywne oddziaływanie na efektywność i wartość spółek należy przypisać zmiennej w postaci tempa wzrostu wartości księgowej kapitału zakładowego, gdyż tylko w pierwszym modelu odnotowano ujemną wartość parametru stojącego przy tej zmiennej.

Na podstawie wyników badań empirycznych wskazać można, iż tempo wzrostu rentowności i wartości badanych spółek w niewielkim stopniu było objaśnione przez zmiany kapitału zakładowego. Najwyższy stopień dopasowania miał miejsce w modelu, gdzie zmienną endogeniczną była rentowność aktywów całkowitych. Świadczy o tym obliczony współczynnik determinacji $R^{2}$, który wyniósł blisko 70\%. Najsłabsze zaś odzwierciedlenie modelu w rzeczywistości gospodarczej należy przypisać zależnościom występującym między miernikami $C / W K$ a zmianami po stronie kapitału zakładowego.

Mając na uwadze powyższe, w ramach podsumowania można dokonać oceny parametrów strukturalnych modeli, pokazując o ile zmieni się zmienna objaśniana jeżeli zmienna objaśniająca zwiększy się o jednostkę. I tak:

- jeśli kapitał zakładowy wzrośnie o $1 \%$, to przy zachowaniu zasady ceteris paribus rentowność aktywów całkowitych spadnie o około $0,19 \%$, rentowność kapitału własnego wzrośnie o około $2,04 \%$, kapitalizacja rynkowa wzrośnie o około $2,74 \%$ oraz wskaźnik ceny do wartości księgowej wzrośnie o około $0,31 \%$

- jeśli udział kapitału zakładowego w majątku całkowitym wrośnie o 1\%, to przy zachowaniu zasady ceteris paribus rentowność aktywów całkowitych wzrośnie o około 1,67\%, rentowność kapitału własnego spadnie o około $10,72 \%$, kapitalizacja rynkowa wzrośnie o około $3,26 \%$ oraz wskaźnik ceny do wartości księgowej wzrośnie o około 3,92\%;

- jeśli udziału kapitału zakładowego w kapitale własnym wrośnie o $1 \%$, to przy zachowaniu zasady ceteris paribus rentowność aktywów całkowitych spadnie o około 0,39\%, rentowność kapitału własnego wzrośnie o około 0,04\%, kapitalizacja rynkowa spadnie o około $0,24 \%$ oraz wskaźnik ceny do wartości księgowej spadnie o około $0,17 \%$.

\section{ZAKOŃCZENIE}

Wielkość i struktura kapitału własnego stanowi ważny problem zarządzania strategicznymi źródłami finansowania przedsiębiorstwa. Jest on zdeterminowany szeregiem różnorodnych czynników i warunków efektywnego działania przedsiębiorstw.

Przeprowadzona analiza wpływu podwyższania kapitału zakładowego na efektywność i wartość wybranych spółek budowlanych pozwala wnioskować, iż 
znacznemu zróżnicowaniu wartości księgowych kapitału zakładowego w badanych spółkach oraz jego udziału w kapitale własnym i całkowitym, towarzyszą znaczące różnice siły i charakteru zależności występujących między poszczególnymi zmiennymi. Wyniki badań empirycznych potwierdzają, iż w analizowanych spółkach giełdowych zaobserwować można zarówno pozytywny, jak i negatywny wpływ zmian kapitału zakładowego, jego udziału w majątku całkowitym oraz w kapitale własnym na kategorie efektywnościowo-wartościowe, czyli rentowność aktywów całkowitych, rentowność kapitału własnego, współczynnik kapitalizacji rynkowej oraz współczynnik cena/wartość księgowa. Wyłącznie pejoratywny wpływ udziału kapitału zakładowego w kapitale własnym na rentowność aktywów całkowitych badanych spółek okazał się istotny statystycznie. Pozostałe oszacowania parametrów modeli nie pozwoliły jednoznacznie potwierdzić występujących zależności.

\section{BIBLIOGRAFIA}

Alavi A., Pham P. K., Pham T. M., Pre-IPO ownership structure and its impact on the IPO process, ,Journal of Banking \& Finance” 2008, no. 32.

Bazy danych Notoria Serwis SA - http://ir.notoria.pl.

Billett M. T., Flannery M. J., Garfinkel J. A., Frequent issuers' influence on long-run post-issuance returns, ,Journal of Financial Economics” 2011, no. 99.

B lack A., Wright P., B a ch man J., W poszukiwaniu wartości dla akcjonariuszy, Wydawnictwo ABC, Kraków 2000.

Brav A., Geczy C., Gompers P. A., Is the abnormal return following equity issuances anomalous?, „Journal of Financial Economics” 2000, no. 56.

B realey R. A., Myers S. C., Marcus A. J., Fundamentals of Corporate Finance, McGraw-Hill, New York 1995.

Brennan M. J., Franks J., Underpricing, ownership and control in initial public offerings of equity securities in the UK, ,Journal of Financial Economics” 1997, no. 45.

$\mathrm{C}$ a i J., We i C. J., The investment and operating performance of Japanese initial public offerings, „Pacific-Basin Finance Journal” 1997, no. 5.

D u d y c z T., Zarzqdzanie wartościa przedsiębiorstwa, PWE, Warszawa 2005.

Dulini e c A., Finansowanie przedsiębiorstwa, PWE, Warszawa 2007.

Duliniec A., Struktura $i$ koszt kapitału w przedsiębiorstwie, Wydawnictwo Naukowe PWN, Warszawa 2001.

Eilenberger G., Betriebliche Finanzwirtschaft, 7. Auflage, Oldenburg Wissenschaftsverlag $\mathrm{GmbH}$, München 2003.

Fe d or o w i z Z Z., Finanse przedsiębiorstwa, Poltext, Warszawa 1993.

Fedorowicz Z., Uwagi o przedmiotowym zakresie teorii finansów przedsiębiorstw, [w:] J. I c ki e wi c z (red.), Problemy finansów w teorii i praktyce, Wydawnictwo SGH, Warszawa 2004.

Fischer E. O., Finanzwirtschaft für Anfünger, 4. Auflage, Oldenbourg Wissenschaftsverlag $\mathrm{GmbH}$, München 2005.

Goławska-Witkowska G., Rzeczycka A., Zalewski H., Zarzqdzanie finansami przedsiębiorstwa, Oficyna Wydawnicza BRANTA, Bydgoszcz 2006. 
Ickiewicz J., Pozyskiwanie, koszt $i$ struktura kapitatu $w$ przedsiębiorstwach, Wydawnictwo Szkoły Głównej Handlowej, Warszawa 2004.

I c ki e w i c z J., Strategia finansowania przedsiębiorstwa, Poltext, Warszawa 1996.

Khurshed A., Initial public offerings. An analysis of the post-IPO performance of UK firms. Unpublished PhD thesis, University of Reading, 1999.

Lj u n g q vist A., IPO underpricing, [w:] B. E. E ckbo (red.), Handbook of Corporate Finance: Empirical Corporate Finance, 2006, vol. A, chapter 7.

Ludwig E., Präsch J., Schikorra U., Finanz-Management, 3. Auflage, Springer Verlag, München 2007.

McNally W. J., S mith B. F., Long-run returns following open market share repurchases, „Journal of Banking \& Finance” 2007, no. 31.

Michalski M., Zarzqdzanie przez wartość. Firma z perspektywy interesów właścicielskich, WIG-Press, Warszawa 2001.

Osta sze w ski J., Ci cirko T., Finanse spótki akcyjnej, Difin, Warszawa 2005.

Pag an o M., Panetta F., Zing ales L., Why do companies go public? An empirical analysis, „Journal of Finance”, 1998, no. 53.

R a p p a o rt A., Wartość dla akcjonariuszy - poradnik, WIG-Press, Warszawa 1999.

Roczne biuletyny giełdowe GPW w Warszawie - http://www.gpw.pl; http://www.gpwinfostrefa.pl.

Ros s S. A., Westerfield R. W., J affe J., Corporate Finance, Irwin, Chicago 1996.

Rozporzadzenie Prezydenta Rzeczypospolitej z dnia 27 czerwca 1934 r. - Kodeks handlowy, DzU 1934, nr 57, poz. 502.

Sajnóg A., Kapitalizacja rezerw a kreowanie wartości giełdowych spótek akcyjnych, „Acta Universitatis Lodziensis", Folia Oeconomica, Wydawnictwo Uniwersytetu Łódzkiego (w druku).

S ajnóg A., Podwyższanie kapitału zakładowego w polskich i niemieckich spótkach akcyjnych, „Przegląd Organizacji” 2013, nr 5.

S ajnóg A., Wptyw kapitalizacji rezerw na dtugookresowa rentowność publicznych spótek gietdowych, „Prace Naukowe Uniwersytetu Ekonomicznego we Wrocławiu” (w druku).

Sierpińska M., W ęd zki D., Zarzqdzanie ptynnościq finansowa w przedsiębiorstwie, Wydawnictwo Naukowe PWN, Warszawa 2008.

S u k a c z D., Pierwsze oferty publiczne na rynkach kapitatowych, CeDeWu.pl, Warszawa 2005.

Szumański A., Dokapitalizowanie spótki kapitałowej, a ochrona przed jej przejęciem, PPH 1997, nr 9.

Te oh S., Welch I., W ong T., Earnings management and the long-run market performance of initial public offerings, ,Journal of Finance” 1998, no. 53.

Ustawa z dnia 15 września 2000 r. - Kodeks spótek handlowych [K.s.h.], DzU 2000, nr 94, poz. $1037 \mathrm{z}$ późn. zm.

Wöhe G., Bilstein J., Ernst D., Häcker J., Grundzüge der Unternehmensfinanzierung, 10. Auflage, Vahlen Verlag, München 2011.

Zalewski H., Finanse firmy w spótkach i innych podmiotach gospodarczych, Wydawnictwo Ośrodka Doradztwa i Doskonalenia Kadr, Gdańsk 2000. 


\section{Artur Sajnóg}

\section{REACTIONS OF EFFICIENCY AND ENTERPRISE MARKET VALUE TO SHARE CAPITAL INCREASE OF CONSTRUCTION COMPANIES}

The major subject of the theoretical-empirical study presented in this paper is the analysis of relation between changes in share capital book value and market value and efficiency of selected public construction companies listed on the Warsaw Stock Exchange. The examined research problem is discussed in three parts. The first part includes the evaluation of influence the process share capital increase on strategic finance management of companies. The second part comprises the results of empirical research on changes in share capital in public construction companies listed on the Warsaw Stock Exchange in the period between 2003-2012. The third part depicts the results of study on strength and character of dependence between share capital shaping and the following ratios: return on total assets, return on equity, market capitalization and price to book value $(P / B V)$.

Key words: efficiency, market value, share capital, share capital increase, joint stock company, companies listed in the Warsaw Stock Exchange. 